\title{
Use of Graduated Syringes for Measuring Salivary Flow Rate: A Pilot Study
}

\author{
Crésio ALVES ${ }^{1}$ \\ Márcia BRANDÃO2 \\ Juliana ANDION ${ }^{1}$ \\ Rafaela MENEZES ${ }^{1}$ \\ ${ }^{1}$ Pediatric Endocrinology Service, University Hospital Professor Edgard Santos, \\ Medical School, Federal University of Bahia, Salvador, BA, Brazil \\ ${ }^{2}$ Dental School, Bahia School of Medicine and Public Health, Salvador, BA, Brazil
}

\begin{abstract}
The evaluation of the salivary flow rate is important in several situations of dental practice. However, weighing the collected salivary volume it is not a practical method in public health services. This work evaluated the use of hypodermic graduated syringes as a simpler alternative method to measure the salivary flow rate. Saliva samples were obtained from 50 individuals ( 31 females and 19 males) aged 8 to 32 years (mean age: 12.4 years), recruited at the outpatient dental clinics of two public health centers. After collection, the saliva was weighed in a graduated scale and the results compared with the volume obtained through its measurement, in mL, in graduated hypodermic syringes. There was a positive and significant relationship between the two methods of measuring salivary flow rates as demonstrated by the Pearson's correlation coefficient $(r=0.996$, with $\mathrm{p}<0.05)$. Measurement of the salivary flow rate using graduated syringes demonstrated to be a reliable method, with lower cost and more practical than the traditional method of salivary weighing.
\end{abstract}

Key Words: saliva, oral health, sialometry, public health.

\section{INTRODUCTION}

The salivary flow measurement is frequently used in the evaluation of oral and systemic diseases (1). The main objective of this procedure is to investigate the presence of hyposalivation which can be caused by various etiologic factors such as: head and neck radiotherapy (2), intake of medications (3), schizophrenia (4), Sjögren's syndrome (5) and diabetes mellitus (6-7). Besides the reduction in salivary flow causing dry mouth, burning mouth and taste disturbance (8), the quality of saliva shows a shift towards a more acidogenic microflora (1).

Methods for measuring salivary volume are divided in those that measure saliva directly from the salivary glands and those that measure the saliva present in the mouth, or the whole saliva (9). The first method is technically difficult and can cause lesions in the Stensen and Wharton ducts. The second method, in spite of being subject to the interference of non-salivary elements, such as epithelial cells and food remainders, is the most used method in clinical practice (10).

The saliva can be obtained with or without stimulus, that is the unstimulated (resting) and the stimulated salivary flow. For stimulated salivary flow, paraffin and citric acid are mainly used, while nonstimulated salivary flow is obtained in the absence of any stimulus (10). Normal non-stimulated salivary flow rate ranges from 0.3 to $0.5 \mathrm{~mL} / \mathrm{min}$, and flow rates between 0.10 and $0.01 \mathrm{~mL} / \mathrm{min}$ are considered hyposalivation.

There are different methods for collecting saliva. The most common methods are: suction, fluid synthetic swab, cotton pledget, hydrocellulose microsponge or passive drooling (11). In most of these methods, after collection, salivary flow is measured by weighing the salivary sample in a graded balance. Unfortunately, graded balances are not always available in the public health dentistry service network.

The aim of this study was to evaluate an alternative method for measuring salivary flow rate, 
by calculating its volume in milliliters with graded hypodermic syringes, comparing the results to those obtained with the traditional technique of measuring the saliva in grams.

\section{MATERIAL AND METHODS}

This was a cross-sectional study conducted over a 1-month period. A convenience sample of 50 individuals (31 females and 19 males) aged 8 to 32 years (mean age: 12.4 years) was obtained at the outpatient dental clinics of two public health centers in the city of Salvador, BA, Brazil. Two examiners (R.M. and J.A.) conducted all testing.

The study was approved by the Medical Research Ethics Committee of the Federal University of Bahia School of Medicine and Public Health in accordance with the 1975's Helsinki Declaration, as revised in 1983. All participants signed an informed consent form authorizing their participation and the tests.

\section{Inclusion Criteria}

Healthy volunteers who agreed to participate in the study and did not meet any of the exclusion criteria.

\section{Exclusion Criteria}

Presence of salivary gland inflammation, parotid gland infection, gingivostomatitis, tonsillitis, dehydration, systemic diseases (i.e., diabetes, Sjögren syndrome) and use of medications that could alter the salivary flow (i.e., atropine, antihistaminic drugs, amphetamines, iodine, mercury and phenotiazidics).

\section{Saliva Collection}

Non-stimulated whole saliva was collected in the morning, 2-3 $\mathrm{h}$ after breakfast, in a ventilated and well illuminated room. The participants were requested to rest for $5 \mathrm{~min}$, with their eyes open, without stimulating salivation, remaining comfortably seated, with their arms resting on their knees, and their heads lowered and facing slightly forwards, between their arms. Before collection, the participants rinsed their mouth with water. Then, after swallowing all the saliva present in the mouth, they were instructed to allow new saliva to accumulate in the mouth, and to expectorate it into a receptacle that was previously weighed in a precision balance (Mettler PC 400, Zurich, Switzerland), every $60 \mathrm{~s}$ for a period of $5 \mathrm{~min}$. After collection, the saliva was placed into ice-chilled boxes and sent immediately to the laboratory.

\section{Salivary Flow Rate Measurement}

Precision balance weighing- The receptacles containing saliva were reweighed in the precision balance. The difference between the value after and before salivary collection was recorded as being the weight of the saliva. The weight was then divided by the time of duration of the collection $(5 \mathrm{~min}$ ) and the flow rate was calculated in $\mathrm{g} / \mathrm{min}$, which is equivalent to $\mathrm{mL} / \mathrm{min}$, since over $99 \%$ of the saliva is composed of water.

Graduated syringes - After weighing, the total saliva collected was aspirated from the collection receptacle with a disposable $5 \mathrm{~mL}$ sterile syringe (Becton-Dikinson-BD, São Paulo, SP, Brazil) avoiding contact with the epithelium. The amount of saliva in $\mathrm{mL}$, divided by the time of duration of the collection was recorded as the mean salivary flow rate. Only the liquid component of the saliva, not the foam, was measured.

\section{Statistical Analysis}

The results obtained with the two methods of measuring salivary flow rate were analyzed by Pearson's Correlation Coefficient, a statistical test that assesses the strength of association between two variables. The magnitude of $r$ describes the strength of association between the variables, and the sign tells the direction of the association. The computer software used was SPSS, version 13.0 (SPSS Inc., Chicago, IL, USA).

\section{RESULTS}

The mean salivary flow rate weighed was $0.33 \mathrm{~mL} / \mathrm{min}(0.08 \mathrm{~mL} / \mathrm{min}-0.67 \mathrm{~mL} / \mathrm{min})$, with a coefficient of variation of $45 \%$; the mean salivary flow rate aspirated with hypodermic syringes was $0.31 \mathrm{~mL} /$ $\min (0.06 \mathrm{~mL} / \mathrm{min}-0.62 \mathrm{~mL} / \mathrm{min})$, with a coefficient of variation of $48 \%$.

The comparison between the two salivary flow rate measurement methods by Pearson's Correlation Coefficient showed a positive and significant association between them $(r=0.996$, and $\mathrm{p}<0.05)$ (Fig. 1).

Both methods diagnosed hyposalivation (flow 
rates between 0.01 and $0.1 \mathrm{~mL} / \mathrm{min}$ ) in $10 \%$ of the patients, in whom there was difficulty with aspiration due to the very small volume of saliva. The amount of foam present in the saliva did not interfere in the aspiration technique.

\section{DISCUSSION}

Saliva is mainly produced by three pairs of major salivary glands (parotid, submandibular and sublingual). It starts the digestive process, mediates taste sensation, helps maintaining the integrity of dental and mucosal tissues, has antimicrobial action, and contributes to mastication and deglutition (9,12-14).

The volumes of saliva vary depending on the type and intensity of stimulation. A good salivary flow protects against dental caries, erosion, abrasion and candidiasis (14). Patients with decreased salivary secretion may present with various medical problems, such as, for example, xerostomia, dry mouth, mucosal inflammation, burning mouth, taste disturbances, tooth tissue demineralization, difficulties with mastication and deglutition and insufficient denture retention $(1,8,9,12)$.

Sialometry is used to diagnose systemic illnesses, to monitor oral mucosal status and general heath and to assess side-effects of medications and chronic diseases. Although salivary flow measurement by means of weighing is the most used method, it is an expensive procedure that requires the acquisition and maintenance of a highly sensitive balance. Therefore, the search of an alternative low cost method was conducted.

In this study, saliva was collected without stimulation. Collection was made by expectoration, as

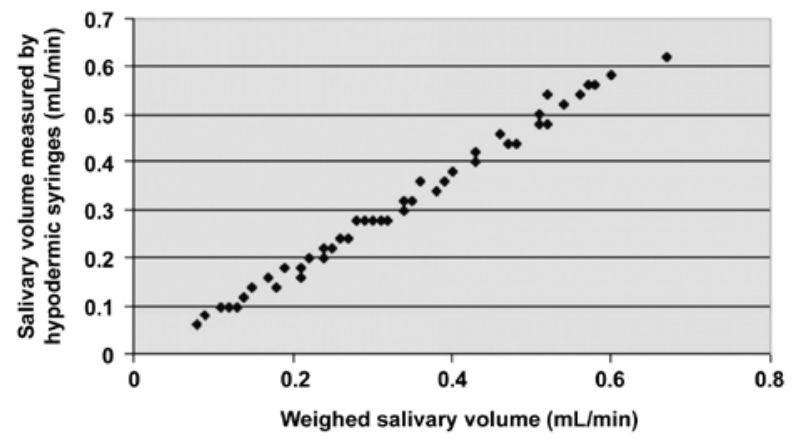

Figure 1. Correlation between the salivary flow rate measured by weight and using graduated hypodermic syringes in millimeters (Pearson's correlation coefficient: $r=0.996 ; \mathrm{p}<0.005$ ). the methods involving suction or use of cotton wool cause a certain degree of stimulation in the oral cavity, which could have prejudiced measurement. Other methods of measuring salivary flow have been recently described. The modified Schirmer test (originally used do assess eye dryness) is an easy and objective method to measure mouth dryness, but requires the acquisition of reagent strips (9). This test is performed with a 4-cm reagent strip impregnated with a blue dye at its end. When the strip contacts moisture, after being placed in the patient's floor of the mouth, the blue dye travels up the strip and can be read at specific intervals (9). Kanehira et al. (15) described a novel assay system comprising 3 spots containing starch and potassium iodide, and a coloring reagent, based on the color reaction of iodinestarch. However, none of these methods are suitable for public health dentistry clinics due to its intrinsic financial costs (15).

The short collection time $(5 \mathrm{~min})$ makes the procedure more practical for the clinician, and more comfortable for the patient. The results of the mean salivary flow rate obtained with the methods used in this study (weighing and aspiration) are within the flow range considered normal (0.3-0.5 mL/min) (16).

The use of an antifoaming agent (octanol, butyl alcohol, dimethicone) to determine the amount of foam in the final volume was not included in the present study because the main goal was to describe the application technique without the need for materials others than the hypodermic syringe.

Variables that could influence salivary flow were minimized in this study by collecting saliva at the same time of the day, excluding medications and oral diseases that could potentially influence the results, and screening patients from the same socioeconomic status. In spite of this, is it possible that differences in fluid or food intake prior to test and different amounts of residual saliva after instructions to swallow could have affected the salivary flow.

The findings of this study, in which the salivary flow rate was measured using graded hypodermic syringes, show that this is an inexpensive, reliable, welltolerated, practical method, with a good correlation with the traditional method of weighting the collected saliva. As this was a pilot-study, further studies with a larger number of participants, including elderly individuals, in whom salivary problems are more prevalent (17), should be done to confirm these preliminary results and lead to recommendation of its large-scale use. 


\section{RESUMO}

A avaliação do fluxo salivar é importante em várias situações da prática odontológica. Porém, sua mensuração é habitualmente realizada através da pesagem do volume coletado, o que não é prático na rede pública de saúde. Esse trabalho teve por objetivo avaliar o uso de seringas hipodérmicas graduadas como alternativa mais simples para mensurar o fluxo salivar. Foram analisadas amostras de saliva de 50 indivíduos (31 mulheres e 19 homens) com idades entre 8 e 32 anos (média:12,4 anos) saudáveis, recrutados no ambulatório de odontologia de dois centros da rede pública de saúde. Após a coleta, a saliva foi pesada numa balança analítica de precisão e comparada com o volume aferido através de sua mensuração em mililitros obtido com o uso de seringas hipodérmicas graduadas. O coeficiente de correlação de Pearson mostrou a existência de uma associação positiva e significativa entre os dois métodos de mensuração do fluxo salivar $(r=0,996$; $\mathrm{p}<0,05)$. Neste estudo-piloto, a medida do fluxo salivar utilizando seringas graduadas mostrou-se um método confiável, de baixo custo e mais prático que o método tradicional de pesagem salivar.

\section{REFERENCES}

1. Tschoppe P, Wolgin M, Pischon N, Kielbassa AM. Etiologic factors of hyposalivation and consequences for oral health. Quintessence Inte 2010;41:321-333.

2. Albuquerque DF, Tolentino ES, Monteiro-Amado F, Arakawa C, Chinellato LE. Evaluation of halitosis and sialometry in patients submitted to head and neck radiotherapy. Med Oral Patol Oral Cir Bucal. 2010;15:e850-e854.

3. Moore PA, Guggenheimer J. Medication-induced hyposalivation: etiology, diagnosis, and treatment. Compend Contin Educ Dent 2008;29:50-55.

4. Praharaj SK, Jana AK, Goswanmi K, Das PR, Goyal N, Sinha VK. Salivary flow rate in patients with schizophrenia on clozapine. Clin Neuropharmacol 2010;33:176-178.

5. Cho MA, Ko JY, Kim YK, Kho HS. Salivary flow rate and clinical characteristics of patients with xerostomia according to its etiology. J Oral Rehabil 2010;37:185-193.
6. Borges BC, Fulco GM, Souza AJ, de Lima KC. Xerostomia and hyposalivation: a preliminary report of their prevalence and associated factors in Brazilian elderly diabetic patients. Oral Health Prev Dent 2010;8:153-158.

7. López ME, Colloca ME, Páez RG, Schallmach JN, Koss MA, Chervonagura A. Braz Dent J 2003;14:26-31.

8. Toida M, Nanya Y, Takeda-Kawaguchi T, Baba S, Iida K, Kato K, et al.. Oral complaints and stimulated salivary flow rate in 1188 adults. J Oral Pathol Med 2010;39:407-419.

9. Chen A, Wai Y, Lee L, Lake S, Woo A. Using the modified Schirmer test to measure mouth dryeness: a preliminary study. J Am Dent Ass 2005;136:164-170.

10. Navazesh M, Kumar SK. Measuring salivary flow: challenges and opportunities. J Am Dent Ass 2008;139:35S-40S.

11. Beltzer EK, Fortunato CK, Guaderrama MM, Peckins MK, Garramone BM, Granger DA. Salivary flow and alpha-amylase: collection technique, duration, and oral fluid type. Physiol Behav 2010;101:289-296

12. De Almeida PV, Grégio AM, Machado AM, de Lima AA, Azevedo LR. Saliva composition and functions: a comprehensive review. J Contemp Dent Pract.2008;9:72-80.

13. Dodds MWJ, Johnson DA, Yeh C. Health benefits of saliva: a review. J Dent 2005;33:223-233.

14. Dawes C. Salivary flow patterns and the health of hard and soft oral tissues. J Am Dent Assoc 2008;139:18S-24S.

15. Kanehira T, Yamaguchi T, Takehara J, Kashiwazaki H, Abe T, Morita M, et al.. A pilot study of a simple screening technique for estimation of a salivary flow. Oral Surg Oral Med Oral Pathol Radiol Endod 2009;108:389-393.

16. Moore PA, Guggenheimer J, Etzel KR, Weyant RJ, Orchard T. Type 1 diabetes mellitus, xerostomia, and salivary flow rates. Oral Surg Oral Med Oral Pathol Oral Radiol Endod 2001;92:281-291.

17. Leal SC, Bittar J, Portugal A, Falcão DP, Faber J, Zanotta P. Medications in elderly people: its influence on salivary pattern, signs and symptons of dry mouth. Gerontology 2010;27:129-133.

18. Wiener RC, Wu B, Crout R, Wiener M, Plassman B, Kao E, et al.. Hyposalivation and xerostomia in dentate older adults. J Am Dent Assoc 2010;141:279-284.

Accepted September 15, 2010 